REVIEWS OF INFECTIOUS DISEASES - VOL. 8, SUPPLEMENT 2 - MAY-JUNE 1986

(C) 1986 by The University of Chicago. All rights reserved. $0162-0886 / 86 / 0802-0019 \$ 02.00$

\title{
Prevention of Travelers' Diarrhea by Nonantibiotic Drugs
}

\author{
Robert Steffen, Rolf Heusser, and Herbert L. DuPont
}

\author{
From the Institute for Social and Preventive Medicine, \\ University of Zurich, Zurich, Switzerland; and the University \\ of Texas Health Science Center at Houston, The Medical \\ School, Houston, Texas
}

\begin{abstract}
Travelers have resorted to a variety of drugs for prevention of diarrhea. No beneficial prophylactic effect has been confirmed for halogenated hydroxyquinolines, lactobacilli, antimotility drugs, ethacridine, and various other agents. In contrast, bismuth subsalicyate (BSS) in liquid form reduced the incidence of diarrhea in students from the United States living in Mexico and in tablet form in volunteers challenged by enterotoxigenic Escherichia coli. In tourists visiting various developing countries, a randomized, doubleblind study was conducted in which 390 persons received a total of 2.1 or $1.05 \mathrm{~g}$ of BSS daily or placebo in tablet form in two doses. BSS reduced the incidence of diarrhea by $41 \%$ in the high-dose group and by $35 \%$ in the low-dose group without causing important adverse reactions.
\end{abstract}

Since the advent of mass travel to exotic tropical destinations, travelers have resorted to a variety of drugs for the prevention of travelers' diarrhea. In 1957 Kean [1] observed that of 1,265 residents of the United States returning from Mexico, $35 \%$ had taken prophylactic medication. According to the author, this figure might have been a slight overestimate of the incidence of prophylaxis. In our more recent surveys, we have found that, depending on their destination, $10 \%-25 \%$ of European travelers take some medication to prevent emporiatric enteritis. Despite the fact that, at least in Europe, we have observed a definite trend away from prophylaxis to therapy by self-medication, the findings of these surveys indicate that it is important to evaluate the effectiveness of prophylaxis. Few data exist from which to judge such trends in travelers from the United States, but it is our impression that chemoprophylaxis is employed in nearly one-half of travelers to high-risk areas. Of the various antidiarrheal agents used, many have not been studied for prevention of travelers' diarrhea. We have limited our evaluation of nonantibiotic drugs in prophylaxis of travelers' diarrhea to six groups of agents.

\section{Hydroxyquinolines}

The first agents to be broadly used for prophylaxis were halogenated hydroxyquinolines. They were originally introduced in 1934 for use in the treatment of

Please address requests for reprints to Dr. Robert Steffen, Institute for Social and Preventive Medicine, University of Zurich, Sumatrastrasse 30, CH-8006 Zurich, Switzerland. intestinal amebiasis. However, it was not until 1958 that their efficacy in the prophylaxis of travelers' diarrhea was evaluated. Kean [1] recruited students from the United States and Canada during college registration for study in Mexico (table 1). Unfortunately, it was impossible to enroll all the study population before or immediately on their arrival; enrollment usually took place on the third day abroad. Using a randomized, double-blind method, Kean compared the efficacy of iodochlorhydroxyquin, which is available commercially as Entero-Vioform (dosage, $375 \mathrm{mg}$ twice a day), with that of neomycin and a placebo. Whereas neomycin was effective, those who were taking iodochlorhydroxyquin showed a slightly increased incidence of diarrhea as compared with those who were taking placebo. Similarly, in the subgroup who started drug prophylaxis on the first day abroad, the active agent did not reduce the incidence of diarrhea. No adverse reactions were reported.

In a second study, a Swedish group investigated the efficacy of dibromoxyquinoline in Scandinavian tourists who were vacationing in the Canary Islands [2]. It is uncertain how the assignment of the tourists to the drug groups was randomized. The active drug was found to be distinctly superior to a placebo. Again, not a single person complained about adverse effects, which is surprising in view of the considerable frequency of such complaints obtained nowadays - even in placebo groups. Mentzing [3] then performed a retrospective assessment of travelers who had returned to Sweden. He demonstrated that those who had taken one of a variety of hydroxyquinolines were more likely to have developed diarrhea, 
Table 1. Efficacy of nonantibiotic prophylaxis of travelers' diarrhea.

\begin{tabular}{|c|c|c|c|c|c|c|}
\hline $\begin{array}{l}\text { Type of agent, } \\
\text { study }\end{array}$ & 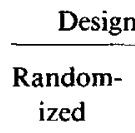 & $\frac{}{\text { DB }}$ & $\begin{array}{l}\text { No. of } \\
\text { subjects }\end{array}$ & $\begin{array}{l}\text { Percentage } \\
\text { with } \\
\text { diarrhea }\end{array}$ & $\begin{array}{c}\text { Significance } \\
\text { level }\end{array}$ & Reference \\
\hline $\begin{array}{l}\text { Halogenated hydroxyquinoline } \\
\text { Iodochlorhydroxyquin } \\
\text { Placebo }\end{array}$ & + & + & $\begin{array}{l}210 \\
202\end{array}$ & $\begin{array}{l}39 \\
34\end{array}$ & NS & 1 \\
\hline $\begin{array}{l}\text { Dibromoxyquinoline } \\
\text { Placebo }\end{array}$ & NR & + & $\begin{array}{l}114 \\
115\end{array}$ & $\begin{array}{r}9 \\
61\end{array}$ & $P<.001$ & 2 \\
\hline $\begin{array}{l}\text { Various hydroxyquinolines } \\
\text { Nothing }\end{array}$ & * & & $\begin{array}{l}256 \\
612\end{array}$ & $\begin{array}{l}40 \\
32\end{array}$ & ND & 3 \\
\hline $\begin{array}{l}\text { Broxyquinolinbenzoxaldin } \\
\text { Nothing }\end{array}$ & - & - & $\begin{array}{l}160 \\
160\end{array}$ & $\begin{array}{r}9 \\
54\end{array}$ & $P<.01$ & 4 \\
\hline $\begin{array}{l}\text { Mexaforme } \\
\text { Nothing }\end{array}$ & - & - & $\begin{array}{l}217 \\
300\end{array}$ & $\begin{array}{l}25 \\
13\end{array}$ & ND & 5 \\
\hline $\begin{array}{l}\text { Iodochlorhydroxyquin }{ }^{\dagger} \\
\text { Placebo }{ }^{\dagger}\end{array}$ & - & - & $\begin{array}{l}499 \\
279\end{array}$ & $\begin{array}{r}3 \\
15\end{array}$ & $P<.001$ & 6,7 \\
\hline $\begin{array}{l}\text { Dichlorhydroxyquinoline } \\
\text { Placebo }\end{array}$ & NR & + & $\begin{array}{l}230 \\
222\end{array}$ & $\begin{array}{l}10 \\
35\end{array}$ & $P<.001$ & 8 \\
\hline $\begin{array}{l}\text { Lactobacilli } \\
\text { Lactobacilli } \\
\text { Placebo }\end{array}$ & + & + & $\begin{array}{l}17 \\
14\end{array}$ & $\begin{array}{l}41 \\
14\end{array}$ & NS & 9 \\
\hline $\begin{array}{l}\text { Lactobacilli } \\
\text { Placebo }\end{array}$ & + & + & $\begin{array}{l}23 \\
25\end{array}$ & $\begin{array}{l}70 \\
68\end{array}$ & NS & 10 \\
\hline $\begin{array}{l}\text { Lactobacilli } \\
\text { Placebo }\end{array}$ & + & + & $212 \ddagger$ & $\begin{array}{l}55 \\
51\end{array}$ & NS & 11 \\
\hline $\begin{array}{l}\text { Ethacridine } \\
\text { Ethacridine } \\
\text { Placebo } \\
\text { Nothing }\end{array}$ & NR & $T$ & $\begin{array}{l}49 \\
49 \\
50\end{array}$ & $\begin{array}{l}18 \\
35 \\
43\end{array}$ & $\begin{array}{l}\text { NS§ } \\
\text { NS }\end{array}$ & 12 \\
\hline $\begin{array}{l}\text { Ethacridine } \\
\text { Placebo }\end{array}$ & + & + & $\begin{array}{r}48 \\
149\end{array}$ & $\begin{array}{l}34 \\
38\end{array}$ & NS & 13 \\
\hline $\begin{array}{l}\text { Various chemoprophylactic ag } \\
\text { Furazolidonell } \\
\text { Placeboll }\end{array}$ & NR & NR & $\begin{array}{l}223 \\
113\end{array}$ & $\begin{array}{l}12 \\
42\end{array}$ & ND & \\
\hline $\begin{array}{l}\text { Furazolidone } \\
\text { Placebo }^{\#}\end{array}$ & NR & NR & $\begin{array}{r}184 \\
88\end{array}$ & $\begin{array}{r}1 \\
10\end{array}$ & ND & 14 \\
\hline $\begin{array}{l}\text { Phthalylsulfathiazole } \\
\text { Placebo }\end{array}$ & NR & NR & $\begin{array}{l}168 \\
168\end{array}$ & $\begin{array}{l}12 \\
24\end{array}$ & $P<.01$ & 15 \\
\hline
\end{tabular}

NOTE. $\mathrm{DB}=$ double-blind; NS = not significant; NR $=$ not reported; and ND = not determined.

* Retrospective study.

$\uparrow$ Twice a day, three times a day, and four times a day in three respective trials.

$¥$ The total number of subjects in the study.

$\S P<.02$ for the comparison of ethacridine vs. nothing.

$\|$ Once a day.

\# Twice a day.

notably salmonellosis. It remains debatable whether the treated and nontreated groups were drawn from equivalent populations.

Other uncontrolled studies have looked at the effectiveness of iodochlorhydroxyquin in the preven- tion of travelers' diarrhea [4-8] (table 1). Because of the association of the drug with the syndrome of subacute myelooptic neuropathy (SMON), which occurs primarily in Japan [16] and rarely in other countries [17], use of this agent cannot be recommended. 


\section{Lactobacilli}

On the assumption that lactobacilli favorably modify the intestinal flora, the efficacy of the commercial preparation Lactinex was tested by two groups: Pozo-Olano et al. [9], who conducted their trial in travelers to Mexico, and Clements et al. [10], who challenged volunteer college students with virulent enterotoxigenic Escherichia coli (ETEC). Recently, Kollaritsch et al. [11] distributed a similar dose of Lactobacillus acidophilus to travelers. In each one of the three studies it was concluded that ingestion of lactobacilli did not reduce the incidence of travelers' diarrhea.

\section{Antimotility Drugs}

As Merson [18] has stated, diphenoxylate, which is marketed as Lomotil, was used, and antimotility agents are still used on occasion for prophylaxis of emporiatric enteritis. However, the efficacy of diphenoxylate for this indication has not been tested.

In contrast, we have tested the efficacy of the active metabolite of diphenoxylate, difenoxine [19], in a controlled pilot study (figure 1). As previously described [13], we evaluated the efficacy of six different compounds among 653 tourists visiting Sri Lanka or Kenya. Difenoxine was included in this trial only because its distributor intended to promote its use for prophylaxis of travelers' diarrhea. Difenoxine significantly reduced the rate of well-being, partly by an increase in the incidence of diarrhea and partly by an increase in the rate of adverse reactions mainly constipation. We concluded that antimotility drugs are not to be recommended for prophylaxis of travelers' diarrhea.

\section{Ethacridine}

In the aforementioned pilot study [13], ethacridine, a local antiseptic agent that was used by the Germans to treat diarrhea in World War II, was reassessed. Richarz [12] claimed that it had a significant beneficial effect in participants on a world cruise, but he compared the treated group with untreated travelers rather than with the placebo group. In our pilot study, no reduction in the incidence of diarrhea was observed, and adverse reactions, mainly nausea, were reported by $38 \%$ of those receiving ethacridine, as compared with $23 \%$ of those in the placebo group.

\section{Other Chemotherapeutic Agents}

In our study [13], which was conducted mainly to exclude ineffective or even harmful agents from a larger survey that is currently under way, we evaluated various chemotherapeutic agents (figure 1). Neither sulfadoxine nor a preparation containing thiamphenicol, nitrafurantoin, and sulfafurazole, with the trade name Fultrexin (Inpharzam, Cadempino, Switzerland), significantly reduced the rate of diarrhea. Only Streptotriad (May and Baker, Dagenham, United Kingdom), which contains streptomycin and three sulfonamides, which is discussed in more detail in these proceedings by Sack [20], reduced the rate of diarrhea and increased the rate of well-being significantly.

More than 20 years ago, phthalylsulfathiazole [15] and furazolidone [14] were reported to exert a prophylactic effect without serious adverse effects, but neither agent is widely used at the present time. An additional preparation, trimethoprim-sulfameth-
Figure 1. Efficacy of drug prophylaxis of travelers' diarrhea (n.s. = not significant). Figure is from a study [13] conducted with 653 subjects from 1979 to $1980 ; 388$ cases were assessable.
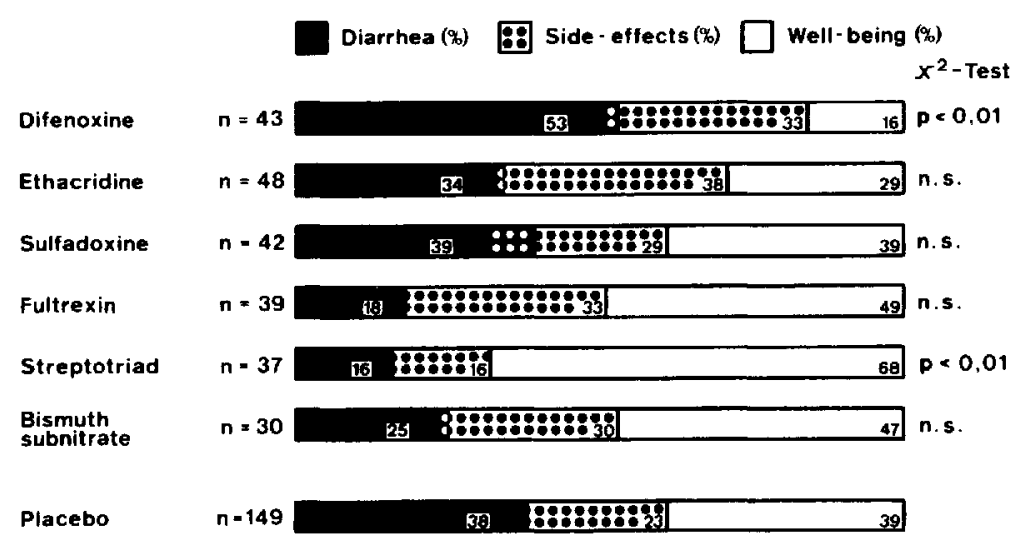
oxazole, can be considered a nonantibiotic compound for prophylaxis, but this agent will be discussed separately.

\section{Bismuth Subsalicylate (BSS)}

Bismuth compounds were introduced to medicine in the 18th century for the treatment of syphilis, yaws, and various gastrointestinal disorders. In the 1920s bismuth replaced mercury as the heavy metal of choice for the intravenous treatment of syphilis until its use started to decline with the discovery and application of penicillin therapy. The value of bismuth salts in treating gastrointestinal disorders has remained unconfirmed [21]. Controlled studies have recently demonstrated that one bismuth salt, bismuth subsalicylate, is effective in both treatment and prophylaxis of travelers' diarrhea.

The initial studies that investigated BSS as a prophylactic agent were carried out in 1977 among students from the United States who were attending summer classes in Guadalajara, Mexico [22]. The volunteers who took the liquid form of the active agent ( $4.2 \mathrm{~g}$ per day) experienced a lower incidence of illness of both mild and moderate levels of severity (table 2). They also experienced fewer other intestinal symptoms. The probabilities of the BSS and placebo groups remaining free of diarrhea during the 21-day study are illustrated in figure 2 . The protection rate, which is defined as the reduction in incidence of diarrhea between the drug and placebo treatments and which is expressed as a percentage such that $100 \%$ indicates maximal protection, was $62 \%$. The preparation was well tolerated; it is notable that the percentages of students with constipation (34\% in the drug vs. $27 \%$ in the placebo group) were not significantly different. Of the students who

Table 2. Efficacy of bismuth subsalicylate (BSS) for prevention of travelers' diarrhea.

\begin{tabular}{|c|c|c|c|c|}
\hline Regimen & $\begin{array}{l}\text { No. of } \\
\text { subjects }\end{array}$ & $\begin{array}{c}\text { Percentage } \\
\text { of subjects } \\
\text { with } \\
\text { diarrhea }\end{array}$ & $\begin{array}{c}\text { Signifi- } \\
\text { cance } \\
\text { level }\end{array}$ & $\begin{array}{l}\text { Ref- } \\
\text { erence }\end{array}$ \\
\hline $\begin{array}{l}\text { BSS, } 60 \mathrm{ml} \text { qid } \\
(4.2 \mathrm{~g} \text { per day })\end{array}$ & 62 & 23 & $P<.0001$ & 22 \\
\hline Placebo & 66 & 61 & & \\
\hline $\begin{array}{r}\text { BSS, } 600 \mathrm{mg} \text { qid } \\
(2.4 \mathrm{~g} \text { per day })\end{array}$ & 15 & 13 & $P<.03$ & 23 \\
\hline Placebo & 16 & 56 & & \\
\hline
\end{tabular}

NOTE. Both studies were randomized and double-blind. did not become ill, enteropathogens were detected in approximately equal numbers in both treatment groups. In contrast, in the patients with diarrhea, an enteropathogen was identified in the stools of $71 \%$ of the placebo-treated vs. $33 \%$ of the BSS-treated students $(P<.05)$. Gorbach [25], who has commented that if travelers were to take BSS at the large dose used in this study $-60 \mathrm{ml}$ four times a day they would need to take an extra suitcase just for their BSS bottles, concluded that this might provide space with which to bring home souvenirs once the drug was consumed. This dose had been arbitrarily chosen in the study [22], and in the report we acknowledged the need to determine the minimum protective dose.

Using volunteers who were challenged with ETEC in a double-blind, placebo-controlled study, Graham et al. [23] set out to determine this dose in a study of the efficacy of the tablet form of BSS. Administration of $600 \mathrm{mg}$ of BSS in the form of two tablets was begun $8 \mathrm{hr}$ before challenge with ETEC and was then continued $2 \mathrm{hr}$ before challenge with ETEC and $2 \mathrm{hr}$ and $4 \mathrm{hr}$ after challenge and on a four-timesdaily regimen for three additional days. Volunteers consumed a total daily dose of $2.4 \mathrm{~g}$ of BSS, which was approximately one-half that used by DuPont et al. in the earlier study [22]. Again, the drug not only reduced to a significant extent the incidence of diarrhea - the protection rate was $77 \%$ - but the two subjects receiving BSS who had diarrhea were the only ones who did not experience accompanying symptoms such as nausea, vomiting, cramps, head-

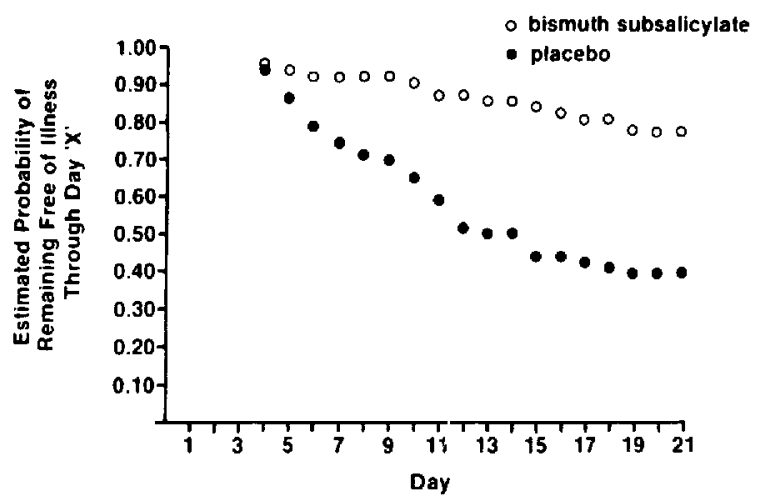

Figure 2. Plot-estimated probabilities of a subject remaining free of illness over 21 days of prophylaxis with bismuth subsalicylate or placebo. The difference between the two "survival" patterns, as assessed by the log-rank method [24], was statistically significant $(P<.001)$. Reprinted with permission from $J A M A$ [22]. 
ache, or fever. Further, ETEC were recovered from the stools of only a few of those receiving a placebo. In addition, in one-half of those receiving BSS, an antibody response to the organism's adhesion fimbriae (CFA I) was demonstrated even in the absence of the development of diarrhea.

To establish a minimal effective prophylactic dose and to test the efficacy of a tablet formulation of BSS in tourists - the population to whom it might later be most frequently recommended - we recently conducted a randomized, triple-blind study evaluating BSS as prophylaxis of travelers' diarrhea (authors' unpublished observations). Three treatment regimens were tested: two 525-mg BSS tablets taken twice daily, two 262.5-mg BSS tablets taken twice daily, and a placebo. Subjects took the medication continuously from the day before departure during the 12-28-day stay in the tropics, until the second day after returning home. Three hundred ten subjects were originally recruited for the study. Twenty-six percent of the persons visited Kenya; $\mathbf{2 3 \%}$, West Africa; $13 \%$, other parts of Africa; $23 \%$, Asia east of India; and $15 \%$, South America. After the exclusion of noncompliant subjects or subjects with nonassessable cases, 231 volunteers could be included in the evaluation of efficacy. The participants were divided into two groups according to the degree of compliance. Excellent compliance was defined as the taking of all but six or fewer tablets of the medication. Fair compliance was defined as the missing of no more than 20 doses.

For both the fair- and excellent-compliance subgroups, the incidence of diarrhea in both the high- and low-dosage groups was significantly reduced as compared with that in the placebo group (table 3). The high incidence of diarrhea in the placebo-group as compared with the incidence found in our epidemiologic studies [26] might primarily be explained by the fact that persons who are prone to suffer from diarrhea were more likely to enroll in the trial. The rates of protection against traveler's diarrhea are shown in table 3. No differences in the efficacy of BSS for travelers to different regions were observed.

A comparison of our results with those of Graham et al. [23] indicates that the frequency of dosing plays an important role in efficacy, since $2.4 \mathrm{~g}$ of BSS given in four doses provided twice the protection of $2.1 \mathrm{~g}$ given in two doses.

In our study, overall adverse effects were reported more frequently in both BSS-treated groups than in the placebo group $(P=.04)$. Constipation and nausea were the principal complaints.

With respect to toxicity, it is important to note that BSS is composed of approximately $60 \%$ bismuth and $40 \%$ salicylate. It is hydrolyzed in the stomach to bismuth oxychloride and salicylate. Over $90 \%$ of the salicylate is absorbed from the gastrointestinal tract and excreted into the urine [27, 28]. In the first study of BSS as prophylaxis [22], the amount of salicylate in the liquid preparation administered to each subject corresponded to that in $8.3325-\mathrm{mg}$ aspirin tablets per day, which is consistent with therapeutic doses of aspirin. This daily dose of BSS would have been equivalent to 3.3 aspirin tablets if the tablet formulation had been used. Although it is not known

Table 3. Prophylactic efficacy of bismuth subsalicylate (BSS) in travelers' diarrhea.

\begin{tabular}{|c|c|c|c|c|c|c|}
\hline \multirow{2}{*}{$\begin{array}{l}\text { Type of } \\
\text { compliance, } \\
\text { daily regimen* }\end{array}$} & \multirow[b]{2}{*}{$\begin{array}{l}\text { No. of } \\
\text { subjects }\end{array}$} & \multicolumn{3}{|c|}{ Travelers' diarrhea } & \multirow[b]{2}{*}{$\begin{array}{c}\text { Significance } \\
\text { level }\end{array}$} & \multirow[b]{2}{*}{$\begin{array}{l}\text { Protection } \\
\text { rate }(\%)\end{array}$} \\
\hline & & Developed & $\begin{array}{l}\text { Did not } \\
\text { develop }\end{array}$ & $\begin{array}{c}\text { Incidence } \\
(\%)\end{array}$ & & \\
\hline \multicolumn{7}{|l|}{ Fair } \\
\hline $2.1 \mathrm{~g}$ of BSS & 88 & 38 & 50 & 43.2 & $P=.014$ & 32.4 \\
\hline $1.05 \mathrm{~g}$ of BSS & 71 & 31 & 40 & 43.7 & $P=.024$ & 31.6 \\
\hline Placebo & 72 & 46 & 26 & 63.9 & & \\
\hline Total & 231 & & & & & \\
\hline \multicolumn{7}{|l|}{ Excellent } \\
\hline $2.1 \mathrm{~g}$ of BSS & 67 & 26 & 41 & 38.8 & $P=.007$ & 40.6 \\
\hline $1.05 \mathrm{~g}$ of BSS & 54 & 23 & 31 & 42.6 & $P=.031$ & 34.8 \\
\hline Placebo & 52 & 34 & 18 & 65.4 & . & \\
\hline Total & 173 & & & & & \\
\hline
\end{tabular}

NOTE. Excellent compliance was defined as the taking of all but six or fewer tablets of BSS; fair, as the taking of all but up to 20 tablets.

* All subjects were to take BSS twice a day. 
whether BSS cross-reacts with aspirin, patients with a history of aspirin-associated allergy should refrain from taking BSS-containing products. In addition, care should be exercised in the administration of BSS to patients receiving anticoagulant therapy, persons with gout, and persons taking probenecid, methotrexate, or other medications that contain aspirin [29].

Between 1973 and 1980, approximately 1,000 cases of bismuth-related encephalopathy were observed in France $[30,31]$ and an additional 40 cases, in Australia [32]. This adverse reaction has also been reported in 12 cases in four other countries [21]. Most cases involved the ingestion of large quantities of bismuth subnitrate or bismuth subgallate (up to $20 \mathrm{~g}$ ) on a daily basis for as long as 30 years. None of the patients had a level of bismuth in blood of $<100$ parts per billion (ppb) [33]. Despite the fact that BSS was introduced early this century, only one case of encephalopathy due to BSS has been reported - in Australia [34]. This occurred in a 60-year-old man who had taken a BSS preparation for a number of years in unknown doses for chronic diarrhea. In addition, this subject was diabetic, had a history of chronic ulcerative colitis, and had undergone surgery for protocolectomy, ileostomy, and splenectomy. No cases of bismuth-induced encephalopathy due to BSS have been reported in North America or have been associated with the use of Pepto-Bismol (Proctor \& Gamble, Cincinnati).

Hillemand et al. [35] have published a review on the relationship of blood bismuth levels and encephalopathy. They concluded that levels of $>100 \mathrm{ppb}$ were toxic, levels of between 50 and $100 \mathrm{ppb}$ were considered an "alarm value," and levels of $<50 \mathrm{ppb}$ were acceptable and should not produce signs of bismuth-induced encephalopathy.
All of the 10 travelers whom we studied who volunteered to give a blood sample within five days after the cessation of treatment had bismuth values that did not exceed $10 \mathrm{ppb}$. In the blood samples that had been obtained in a previous study [22] from six subjects within $24 \mathrm{hr}$ of their discontinuation of daily ingestion of $4.2 \mathrm{~g}$ of BSS for 21 days, all levels were below the assay detection limit of $50 \mathrm{ppb}$ [36].

In a study conducted by Procter \& Gamble (unpublished data), 30 subjects were administered three Pepto-Bismol tablets either four times a day (3.14 $\mathrm{g}$ of BSS per day) or twice a day (1.57 $\mathrm{g}$ of BSS per day) for six weeks. Blood samples were analyzed for bismuth before the start of treatment, at the end of weeks $1,2,4$, and 6 of treatment, and nine weeks after cessation of treatment. The mean \pm SD blood bismuth levels of subjects taking 1.57 and $3.14 \mathrm{~g}$ of BSS per day were $10.0 \pm 6.6$ and $15.0 \pm 7.9 \mathrm{ppb}$, respectively, at the end of six weeks of treatment. Figure 3 shows the mean blood bismuth values observed during this study in the four-times-a-day group. The highest blood bismuth level was recorded in an individual receiving the low dose at week 4 (34 $\mathrm{ppb})$. None of the subjects showed any signs of neurotoxicity, and all blood bismuth levels decreased to below the detection limit at nine weeks posttreatment. Results of this study suggest that bismuth, unlike salicylate, is poorly absorbed from the gastrointestinal tract. In addition, there is no evidence to suggest that BSS, when taken by adults in reasonable doses for up to three weeks for prophylaxis, would result in bismuth-related encephalopathy.

Levine [37] has pointed out that Pepto-Bismol tablets, unlike the liquid form, contain $350 \mathrm{mg}$ of calcium carbonate. Although most persons are able to excrete excess calcium, it has been suggested that prophylactic treatment with BSS tablets in some in-

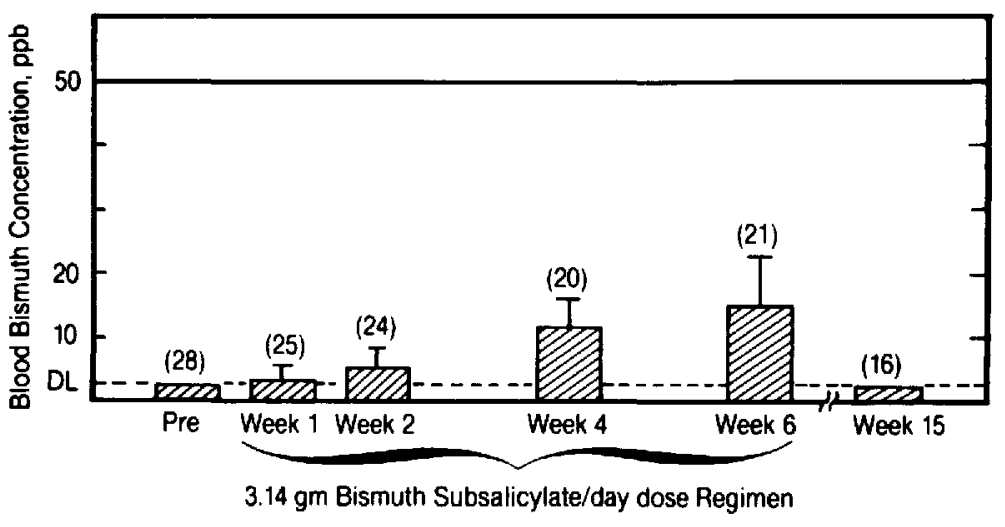

Figure 3. Bioavailability of bismuth after ingestion of $3.14 \mathrm{~g}$ of bismuth subsalicylate per day in divided doses four times daily. Reprinted with permission from an unpublished study (IB-101; Proctor \& Gamble, Cincinnati). 
dividuals may produce a hypercalcemia via the milkalkali syndrome. The minimum amount of calcium reported to produce this syndrome exceeds that consumed in the recommended prophylactic dose. In addition, the Food and Drug Administration has concluded in its review of over-the-counter antacid ingredients that up to $8 \mathrm{~g}$ of calcium carbonate may be consumed daily [38], a value in excess of any reasonable prophylactic dose of BSS.

Recently, evidence has been put forward to suggest a mechanism of action of BSS. The decreased recovery of enteropathogens from the stools of patients given BSS in the earlier studies $[22,23]$ implies that BSS may have bactericidal activity. Graham reported that the challenge strain that was used in his study was sensitive to BSS. Further, Manhart [39] dernonstrated in vitro that BSS and, to a lesser extent, bismuth oxychloride and salicylate, inhibited growth of the most common enteropathogens at concentrations that are likely to be achieved in the upper small intestine (figure 4). Additionally, salicylates have been shown to exhibit an antisecretory effect by increasing net water absorption in intestinal tissue after exposure to bacterial toxins $[40,41]$. The reduced serologic response to infection in experimentally induced ETEC infection by pretreatment with BSS suggests that the drug may interfere with attachment of organisms to intestinal receptors. Additionally, in a series of in vitro studies, the inhibition by BSS of crude toxins of $E$. coli and Vibrio cholerae was demonstrated [42]. It should be noted that neither bismuth subcarbonate [36] nor bismuth subnitrate [13] showed a significant prophylactic effect. Although there is evidence that a number of factors may contribute to the overall efficacy of BSS, precisely how and to what extent each of the components contributes to the action of BSS remains to be elucidated.

\section{Conclusions}

Three types of prophylaxis of travelers' diarrhea are available to the traveler. The first approach, to take no prophylaxis at all, is very reasonable, at least for the majority of travelers to the developing world with the possible exceptions of the high-risk travelers described previously and of those who have to fulfill important tasks during a brief stay abroad. Prophylactic antibiotics are an alternative but certainly have the important disadvantages of potential serious adverse effects and induction of resis-

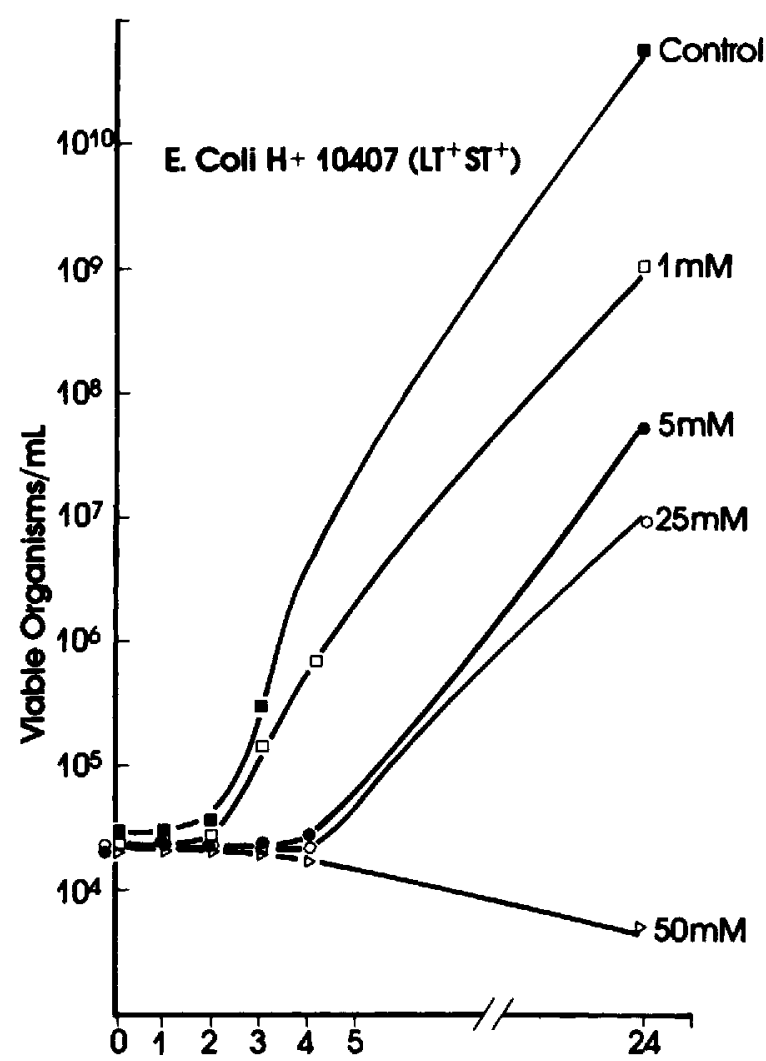

Figure 4. Dose-dependent inhibition of growth of enterotoxigenic Escherichia coli by bismuth subsalicylate. Overnight cultures of ETEC were grown in brain-heart infusion broth (BHI). Growth in the presence of the compounds was examined by inoculating $30 \mathrm{ml}$ of $\mathrm{BHI}$ containing the compound with $0.1 \mathrm{ml}$ of a late log-phase culture and incubating at $37^{\circ} \mathrm{C}$ on a rotating platform. Abbreviations: LT $=$ heat-labile; ST $=$ heat-stable (enterotoxin properties). Figure is from [39].

tant strains in regions frequently visited by tourists [43]. The data presented suggest that only one nonantibiotic agent, BSS, be considered for prophylaxis. BSS has been repeatedly tested under controlled conditions and appears to be safe and effective in the prevention of travelers' diarrhea. The reported studies of BSS suggest that the dosage and especially the number of daily doses are important. One gram of BSS daily taken in two divided doses appears to be the minimum efficacious dose, but a protection rate in the range of $40 \%$ is not sufficient. However, on the basis of the earlier studies [22, 23], the traveler can be protected satisfactorily with a slightly higher dose when the drug is taken more frequently. Because of the convenience of the solid preparation, we currently recommend it and suggest that 
it be administered in a dose of two tablets $(262.5 \mathrm{mg}$ per tablet) three times a day (with meals) during the period at risk for up to three weeks. This dosing schedule represents an extrapolation from the studies reported herein. The efficacy of this approach remains to be investigated.

\section{References}

1. Kean BH, Waters SR. The diarrhea of travelers. III. Drug prophylaxis in Mexico. N Engl J Med 1959;261:71-4

2. Hyllner $S$, Heinlaid $H$, Thorsson $K G$. Fenilor (dibromoxikinolin)-ett nytt tarmantiseptikum. Svenska Lakartidingen 1962;59:2431-54

3. Mentzing LO, Ringertz $O$. Salmonella infection in tourists. 2. Prophylaxis against salmonellosis. Acta Pathol Microbiol Scand 1968;74:405-13

4. Marth W. Prospektive Untersuchungen über Urlaubsdiarrhoen. Therapie der Gegenwart 1968;107:1053-62

5. Malot J, Jaouen H. Essai de prophylaxie des diarrhées dites "de voyage." Revue d'Informations du Corps Médical 1971;31:11-14

6. Richards DA. A controlled trial in travellers' diarrhoea. Practitioner 1970;204:822-4

7. Richards DA. Prophylactic value of clioquinol against travellers' diarrhoea [letter]. Lancet 1971;1:44-5

8. Havlík J, Kocna A. Chemoprofylaxe tzv. průjmů cestovatelů. Cas Lek Cesk 1977;116:199-201

9. Pozo-Olano J de D, Warram JH Jr, Gómez RG, Cavazos MG. Effect of a lactobacilli preparation on travelers's diarrhea: a randomized double-blind clinical trial. Gastroenterology 1978;74:829-30

10. Clements ML, Levine MM, Black RE, Robins-Browne RM, Cisneros LA, Drusano GL, Lanata CF, Saah AJ. Lactobacillus prophylaxis for diarrhea due to enterotoxigenic Escherichia coli. Antimicrob Agents Chemother 1981;20:104-8

11. Kollaritsch H, Stemberger H, Ambrosch P, Ambrosch F, Widermann G. Prophylaxe der Reisedi-rhö mit einem Lyophilisat von Lactobacillus acidophilus [a. stract no. 92]. In: Gemeinsame Tagung der Deutschen Tropenmedizinischen Gesellschaft, Oesterreichischen Gesellschaft für Tropenmedizin und Parasitologie, Schweizerischen Gesellschaft fur Tropenmedizin und Parasitologie. Garmisch-Partenkirchen, Federal Republic of Germany, 1983

12. Richarz A. Prophylaktische und therapeutische Wirkung von Aethacridinlaktat bei unspezifischen Durchfallerkrankungen. Medizinische Klinik 1967;62:1308-10

13. Steffen R, Gsell O. Prophylaxis of traveller's diarrhoea. J Trop Med Hyg 1981;84:239-42

14. Nelson SRC, Jones HL, Ross JB. Trial of furazolidone as a prophylactic in 'traveller's diarrhoea.' Practitioner 1962;188:654-5

15. Kean BH, Schaffner W, Brennan RW, Waters SR. The diarrhea of travelers. V. Prophylaxis with phthalylsulfathiazole and neomycin sulphate. JAMA 1962;180:367-71

16. Tsubaki T, Honma Y, Hoshi M. Neurologic syndrome associated with clioquinol. Lancet 1971;1:696-7
17. Baumgartner G, Gawel MJ, Kaeser HE, Pallis CA, Rose FC, Schaumburg HH, Thomas PK, Wadia NH. Neurotoxicity of halogenated hydroxyquinolines: clinical analysis of cases reported outside Japan. J Neurol Neurosurg Psychiat 1979;42:1073-83

18. Merson M. Toxigenic turista [editorial]. N Engl J Med 1975;292:969-70

19. Rubens R, Verhaegen H, Brugmans J, Schuermans V. Difenoxin ( $R$ 15 403), the active metabolite of diphenoxylate ( $R$ 1132). 5. Clinical comparison of difenoxine and diphenoxylate in volunteers and in patients with chronic diarrhea. Arzneimittel-Forschung. Drug Research 1972; 22:526-9

20. Sack RB. Antimicrobial prophylaxis of travelers' diarrhea: a selected summary. Rev Infect Dis 1986;8(Suppl 2):S160-6

21. Winship KA. Toxicity of bismuth salts. Adverse Drug Reaction and Drug Poisoning Reviews 1983;2:103-21

22. DuPont HL, Sullivan P, Evans EG, Pickering LK, Evans DJ, Vollet JJ, Ericsson CD, Ackermann PB, Tjoa WS. Prevention of traveler's diarrhea (emporiatric enterititis): prophylactic administration of subsalicylate bismuth JAMA 1980;243:237-41

23. Graham DY, Estes MK, Gentry LO. Double-blind comparison of bismuth subsalicylate and placebo in the prevention and treatment of enterotoxigenic Escherichia coliinduced diarrhea in volunteers. Gastroenterology 1983;85:1017-22

24. Peto R, Pike MC, Armitage P, Breslow NE, Cox DR, Howard SV, Mantel N, McPherson K, Peto K, Smith PG. Design and analysis of randomized clinical trials requiring prolonged observation of each patient. II. Analysis and examples. Br J Cancer 1977;35:1-39

25. Gorbach SL. How to avoid running with Escherichia coli. JAMA 1980;243:260-1

26. Steffen R, van der Linde F, Gyr K. Schär M. Epidemiology of diarrhea in travelers. JAMA 1983:249:1176-80

27. Feldman S, Chem S-L, Pickering LK, Cleary TG, Ericsson CD, Hulse M. Salicylate absorption from a bismuth subsalicylate preparation. Clin Pharmacol Ther 1981;29:788-92

28. Pickering LK, Feldman S, Ericsson CD, Cleary TG. Absorption of salicylate and bismuth from a bismuth subsalicylate-containing compound (Pepto-Bismol). J Pediatr 1981; 99:654-6

29. Henderson IWD. Warning against products containing bismuth subsalicylate [letter]. Can Med Assoc J 1980;123:848

30. Buge A, Supino-Viterbo V, Rancurel G, Pontes C. Epileptic phenomena in bismuth toxic encephalopathy. J Neurol Neurosurg Psychiatry 1981;44:62-7

31. Galland MC, Rodor F, Jouglard J. Bismuth et encéphalopathie. Médecine et Hygiène 1979;37:2579-82

32. Burns R, Thomas DW, Barron VJ. Reversible encephalopathy possibly associated with bismuth subgallate ingestion. Br Med J 1974;1:220-3

33. Carruzzo F. L'encéphalopathie bismuthique myoclonique: une intoxication insolite. Rev Med Brux 1980;21:997-1000

34. Hasking GJ, Duggan JM. Encephalopathy from bismuth subsalicylate [letter]. Med J Aust 1982;2:167

35. Hillemand $P$, Pallière $M$, Laquais $B$, Bouvet $P$. Traitement bismuthique et bismuthémie. Sem Hop Paris 1977;53: $1663-9$ 
36. Ericsson CD, DuPont HL, Pickering LK. Bismuth preparations for diarrhea [letter]. JAMA 1980;244:1435-6

37. Levine RA. Risk of hypercalcemia from prophylaxis of traveler's diarrhea. JAMA 1983;249:1151-2

38. Food and Drug Administration. Federal Register 1974 (June): 39, no. 108:19875

39. Manhart MD. Bismuth subsalicylate inhibits growth of enteropathogenic bacteria [abstract no. 820]. In: Program and abstracts of the 24th Interscience Conference on Antimicrobial Agents and Chemotherapy. Washington, DC: American Society for Microbiology, 1984

40. Burke V, Gracey M. Effects of salicylate on intestinal absorp- tion: in vitro and in vivo studies with enterotoxigenic microorganisms. Gut 1980;21:683-8

41. Burke V, Gracey M. Reduction by aspirin of intestinal fluidloss in acute childhood gastroenteritis. Lancet 1980; 1:1329-30

42. Ericsson CD, Evans DG, DuPont HL, Evans DJ Jr, Pickering LK. Bismuth subsalicylate inhibits activity of crude toxins of Escherichia coli and Vibrio cholerae. J Infect Dis 1977;136:693-6

43. DuPont HL, Ericsson CD, Johnson PC. Chemotherapy and chemoprophylaxis of travelers' diarrhea. Ann Intern Med 1985;10:260-1 